\title{
The crisis of contemporary linguistics vs. applied linguistics
}

\author{
Roman Kvapil - Martina Siposova
}

DOI: 10.18355/XL.2020.13.01.12

\begin{abstract}
The role of applied linguistics and its significance as social science is justified and legitimate at present. It surveys the increasing dialogue between linguistics and social theory. It is characterized by various literary sources as a discipline which exploits the results of linguistics and other scientific disciplines in practice. The article deals with the questions of linguistics, applied linguistics, and the role of some sub-disciplines in the system of applied linguistics. The authors analyse the term application and consider diverse interpretations of the term applied linguistics in the broad and narrow sense of the word.
\end{abstract}

Key words: American structuralism, applied linguistics, didactics, generative grammar, linguistics applied, linguodidactics, politolinguistics

\section{Introduction}

The history of linguistics represents the development of the main linguistic trends from the beginning (i.e. Ancient Greece) until present-day. Although modern linguistics, which began to develop in the beginning of the 19th century with the focus on Indo-European studies and lead to a complex reconstruction of the Proto-IndoEuropean language, the first half of the 20th century was marked by the structuralist school based on the work of Ferdinand de Saussure in Europe and Edward Sapir and Leonard Bloomfield in the United States. Since the 1950s, which was marked by turbulent development in natural sciences, the trends in linguistics lead to the emergence of modern interdisciplines. With regard to so called scientific and technological revolution, new linguistic disciplines have been developed. These disciplines usually draw from two or more traditional linguistic disciplines, thus standing on the borderline. It is important to emphasize that many research results obtained from boundary disciplines enriched the conciseness and progress in the field of linguistics. Therefore, alike the development and discoveries in natural sciences, the development in the field of linguistics can be granted on condition we step out of the comfort zone. The subject of the following study are reflections on the current position of linguistics in the system of social sciences. The authors of the article aim to define the concept of applied linguistics, characterize selected linguistic disciplines within the scope of applied linguistics, and to present the model of understanding and interpretation of applied linguistics on the background of existing theories of applied linguistics.

\section{The crisis in modern linguistics}

The mutual influence of sciences can be traced back mainly in the 19th ct., e.g. the dominant position of physics and biology in the 19th ct. had an impact on linguistics. Consequently, experimental phonetics and some biologically oriented theories within the scope of comparative and historical grammar emerged. However, this influence has to be viewed as unilateral. We can hardly find any evidence of the scientific impact of contemporary linguistics on physics or biology.

Nowadays, the situation concerning the shift from traditional division of scientific disciplines, e.g. physics, chemistry and biology led to the integration of, e.g. mathematics and computational science. Thus, there has been a growing tendency towards reciprocal influence of various scientific disciplines, for instance the mutual

XLinguae, Volume 13 Issue 1, January 2020, ISSN 1337-8384, eISSN 2453-711X 
influence of mathematics and logics on linguistics. In practice, this means that not only linguists are increasingly forced to deal with mathematical methods in linguistic research and the application of logics in linguistics, but also mathematicians and logicians are forced to engage in particular issues that have been solely the domain of linguists. The most important thing for us, however, is the fact that, e. g. the collaboration of mathematicians and linguists has raised some new issues that have not been addressed in either mathematics or linguistics yet. Modern interdisciplinary disciplines arise not only at the interface of linguistics and mathematics, but also by the mutual contact between linguistics and some other social sciences, especially psychology, sociology, philosophy and the like. Therefore, such fields as psycholinguistics, sociolinguistics, philosophy of language, etc. are increasingly important nowadays. In terms of interdisciplinary contacts, semantics and semiotics have a special position, that means they are the focus of linguists, mathematicians, logicians, but also psychologists, sociologists, philosophers and the like.

The emergence and turbulent development of new scientific disciplines suggests that we can see a breakthrough in science as such. Obviously, this can also be said with certainty about linguistics, in which the emergence of a large number of modern interdisciplinary disciplines is indicative both of a crisis of traditional linguistics and of the fact that all linguistics so far could be revised in significant ways in the foreseeable future. It offers a certain analogy with the development of linguistics in the 19th ct. in which there prevailed a single massive stream of comparative and historical grammar. The culmination of this process in the late 19th ct. led to the emergence of a young grammarians movement, so called neogrammarians. At the turn of the 19th and 20th centuries, this stream was replaced by a number of new directions, which were differently focused and played a different role in its re-evaluation. However, as a whole, it marked the rise of structuralism. In the early 20th century, Ferdinand de Saussure $(1857$ - 1913) introduced the idea of language as a static system of interconnected units defined through the oppositions between them. He (1986) distinguished between the notions of langue (language as an abstract system) and parole (language as a concrete manifestation of this system, the specific utterance of speech) in his formulation of structural linguistics. Moreover, he also introduced several basic dimensions of linguistic analysis that are still foundational in many contemporary linguistic theories, such as the distinctions between syntagm and paradigm. Apart from linguistics, the structuralist mode of reasoning has been applied in a diverse range of fields, including anthropology, sociology, psychology, literary

criticism, economics and architecture. Among the most prominent thinkers associated with structuralism there are Claude Lévi-Strauss as well as linguist Roman Jakobson. Saussure's Course in General Linguistics influenced many linguists between the two world wars. It gave rise to the subsequent Prague, Moscow and Copenhagen schools of linguistics. It was a prominent direction on a global scale until the 1960s. However, in the late 1950s and early 1960s structural linguistics was facing serious challenges from Noam Chomsky's theory. The 1960s saw the rise of many new fields in linguistics, such as Noam Chomsky's generative grammar, William Labov's sociolinguistics, Michael Halliday's systemic functional linguistics and also modern psycholinguistics.

The current situation in linguistics suggests the distinctly interdisciplinary nature of modern interdisciplinary disciplines, which can be understood in two ways. It is not only that linguistic methods are always combined with the method of one or several other disciplines, e.g. psychology, neurology, sociology, etc., thus creating new sub-branches in the field, such as psycholinguistics, neurolinguistics, sociolinguistics, etc. There are many interfaces, overlaps and common themes that are the focus of interest. Moreover, in addition to the central themes we can find a number of such questions that are of interest to two, three or more boundary disciplines. It has 
to be pointed out that it is very difficult to set the clear-cut boundaries of various disciplines. With some tolerance, this is possible in mathematical linguistics where the division into quantitative, algebraic and computational linguistics has become common. Since the issues of linguistics research have become more interrelated, it is essential to include more sub-branches in order to deal with them. It is even neither tenable to set precise boundaries among linguistic disciplines, nor to establish a hierarchy. On the one hand, all this confirms the idea of a crisis of contemporary linguistics, but on the other hand, it is undisputed that in linguistics, as in other scientific disciplines, we simply do not even try to calculate the exact number of individual disciplines and define their boundaries according to the positivist perspective. Contrary, there is a tendency to recognize that transitions between disciplines are gradual, their interrelationships are complex and establishing their hierarchy depends on the point of view of experts in the field. Such a liberal conception of the nature of the interdisciplinarity of various boundary disciplines undoubtedly corresponds to their true nature and reflects the complex interrelationships that exist among them. On the other hand, such a broad understanding can hardly be applied when dealing with the issues of boundary disciplines comprehensively. Therefore, due to methodological reasons, it is necessary to establish at least the provisional boundaries of the linguistic disciplines in order to determine the subject-matters of their research as well as to determine the aims of such disciplines.

Regarding the division of fields of study within the scope of social sciences - contemporary linguistics, Cerny (1996, p. 461) distinguishes six broad disciplines, to which so called lower-ranking sub-disciplines of contemporary linguistics (e.g. pragmalinguistics, text linguistics, paralinguistics, etc.) can be assigned. Nevertheless, it would be difficult, and even incorrect to subordinate them to each other, such as neurolinguistics, sociolinguistics, ethnolinguistics, semiotics and the philosophy of language. Cerny (1996) considers this division as tentative. Establishing the distinction in social-science boundary disciples is questionable. It is important to realize that it is not a combination of linguistics with another purely social science, in particular psychology, neurology, or semiotics. The focus of interest of these fields of study lies in their common issues and the subject-matters of the research.

\section{Introduction to applied linguistics}

The roots of applied linguistics can be traced back in the late 1950s. The roots of applied linguistics are undoubtedly related to the advent of generative and transformational grammar, which pushed the dominant descriptivism aside. The term Applied Linguistics (AL) is an Anglo-American coinage. It was founded first at the University of Edinburgh School of Applied Linguistics in 1956, then at the Center of Applied Linguistics in Washington, D.C. in 1957 (BALL, 1994). Based on this, it can be stated applied linguistics itself began to form in the context of Western linguist thought, especially in the United States of America thanks to Chomsky, but it has gradually boomed not only in Europe but also in other countries of the world.

The basic literature in this field include studies of Russian linguists J. D. Apresyan, titled Ideas and methods of contemporary structural applied linguistics (1967 ); B. J. Gorodecky's New in foreign linguistics. Applied linguistics (1983); V. A. Zvegincev's Theoretical and applied linguistics (1968); A. E. Kubrik's Introduction to language science (2019); R. Jakobson's Linguistics in its relation to other sciences (2013). Among the western-oriented linguistics, the best-known works on applied linguistics include Concise Encyclopedia of Applied Linguistics (2010) by M. Berns; Applied Linguistics (2010) by G. Cook; A Handbook of Applied Linguistics (2004) by A. Davies; Encyclopedia Dictionary of Applied Linguistics (1998) by K.

XLinguae, Volume 13 Issue 1, January 2020, ISSN 1337-8384, eISSN 2453-711X 
Johnson and H. Johnson; Spoken Language and applied linguistics (1998) by M. McCarthy; Introduction to Applied Linguistics (2010) by N. Schmitt.

In addition to the above-mentioned literary sources from the field of applied linguistics, there are a number of international societies that focus their research on applied linguistics. These include: American Association for Applied Linguistics (http://www.aaal.org), Center for Applied Linguistics (http://www.cal.org), Canadian Association of Applied Linguistics (http://www.aclacaal.org), Mexicana de Linguistic Aplicada (http://www.cele.unam.mx/amla), Linguistic Association and the Latin American Philology (http://www.mundoalfal.org), etc. Among the most well-known European linguistic societies there are Belge de linguistique Appliquée (http://www.abla.be), Asociación Española de Linguistic Aplicada (http://www.aesla.uji.es), Finlandaise de linguistique Appliquée (http://www.cc.jyu.fi), Française de linguistique Appliquée Association (http://www.afla-asso.org), Italian Association of Linguistic Applicata (http://www.aitla.unimo.it), Néerlandaise de linguistique Appliquée (http://www.aila.info/about/org), Norvegienne de linguistique Appliquée (http://www.hf.ntnu.no/anla), Suédoise de linguistique Appliquée (http: / /www.nordiska.su.se/asla), Suisse de linguistique Appliquée (http://www.valsasla.ch/cms), British Association for Applied Linguistics (http://www.baal.org.uk), Estonian Association of Applied Linguistics (http://www.eki.ee/rakenduslingvistika), Gesellschaft für Angewandte Linguistik (http://www.gal-ev.de), Greek Applied Linguistics Science Association (http://www.enl.auth.gr/gala), the Irish Association for Applied Linguistics (http://www.iraal.ie).

In the early 1960s, applied linguistics had some basic features of an independent scientific discipline, especially educational programs, its own university institutes, its own journal. In 1964, the position of applied linguistics was also intensively dealt with by international research organizations and the first international trade union congress. After two years of preparation with financial support from the Council of Europe, the International Association of Applied Linguistics (Association Internationale de Linguistique Appliquée/AILA) was established, and in the same year its first congress was held in Nancy, France. Both areas of interest in applied linguistics - foreign language teaching and machine translation - were officially recognized at the congress. National organizations of applied linguistics were subsequently established - in 1967, Great Britain, British Association of Applied Linguistics, and in 1968 Gesellschaft für Angewandte Linguistik in Germany.

In the 1970s, applied linguistics gained the last attributes of a constituted scientific discipline - university textbooks and compendia (Stephen Pit Corder, Introducing Applied Linguistics, 1973; John Patrick Brierley Allen and Stephen Pit Corder, four-volume The Edinburgh Course in Applied Linguistics, 1973/1975). Subsequently, national associations were established in other countries. In 1977, American Association for Applied Linguistics (AAAL), later Austrian Verband für angewandte Linguistik, etc. AAAL is one of the largest organizations with more than 1,200 members not only from the United States and Canada, but also from 40 other countries around the world. It focuses on language topics, including language learning, language acquisition and language loss, bilingualism, discourse analysis, literacy, rhetoric, stylistics, language for specific purposes, psycholinguistics, foreign and second language teaching, language evaluation and assessment, language policy and language planning. Likewise, the Gesellschaft für Angewandte Linguistik lists around 1,000 members and therefore it is one of the best-known linguistic organizations in the German-speaking countries. There has not been established a Slovak organization of applied linguists yet. In some applied fields, in particular in language teaching, its function may be partially substituted by individual language 
associations, e.g. Association of Russianists of Slovakia, Association of Germanists, Association of Hispanists, Association of Slovak Language Teachers and the others.

Applied linguistics is based on the principles and procedures of theoretical linguistics, especially American structuralism. Since 1960, however, its scope has expanded to the area of language skills assessment, language policy and foreign language teaching. The research of applied linguistics focused on real world problems, the central theme of which is the language of society. In the United States, applied linguistics is understood as the application of structural linguistic knowledge to the teaching of English and foreign languages. Leonard Bloomfield (1887 - 1949), an American linguist, whose book Language (1933) presented a comprehensive description of American structural linguistics, contributed to the development of a curriculum focused on teaching foreign languages, based on the adherence to behaviorism. Another American structural linguist and language teacher, Charles Fries (1887 - 1967), also considered as the father of Audio-Lingual Method in language teaching, is well-known for his foundation of the English Language Institute (ELI) at the University of Michigan in 1941. His contribution can be characterized by conducting intensive diachronic and synchronic studies of the English language, preparation of a series of English-language textbooks for foreigners and developing so called scientific principles for the study of foreign languages. Bloomfield's influence on linguistics is so strong that the entire American linguistics from the mid-twenties to the mid-fifties can be described as Bloomfieldian. Bloomfield's greatest contribution is the consistent description of grammatical phenomena. It is a very detailed and original description of grammar which can also be applied to the methodology of foreign language teaching. Bloomfield states that in studying a language it is not enough to examine only its lexical and semantic component, but it is also necessary to study grammar; combination of language forms. In his view, different language forms put in the same position have different meanings. In 1948 The Journal of Applied Linguistics was published, the first journal dealing with the real language problems of the world. The activities of Bloomfield and the University of Michigan were the basis for the establishment of an American Association for Applied Linguistics. American structuralism is based primarily on the analysis of the morphological structure of language. According to Leitner (1991, p. 126-127), Fries's last major work Structure of English (1952) is a modal of signals grammar focusing on sentence structure. Fries used frame sentences embodying the signals by which English speakers recognize word classes in order to define four major parts of speech (nouns, verbs, adjectives, and adverbs). Fries's important contribution is the principle of explicitly recognizing the signals that mark the classes rather than the individual classes or particular signals he identified. Charles Fries in fact used the principle of function, or combinability (the position of a word in the sentence is the syntactic function of word). In his work Structure of English, he speaks about of a sentence as a closed grammatical structure. He works with the concepts, such as a frame and a substitution (Cerny, 1996, p. 207). A sentence Tento chlieb je dobrý is a frame in which particular constituents can be substitued by different constituents which have the same function within the sentence: Tento chlieb je dobrý (tamten, čerstvý, včerajši atd'). Tento chlieb je dobrý (zvyk, človek, koncert atd'.). Tento chlieb je dobrý (bol, nie je, bol by atd'). Tento chlieb je dobrý (zlý, čerstvý, tvrdý, etc.). Another descriptive theory is based on immediate constituent analysis, so called IC-analysis. It is a method of sentence analysis that was first mentioned by Leonard Bloomfield. IC-analysis divides up a sentence into major parts or immediate constituents, and these constituents are in turn divided into further immediate constituents. The process continues until irreducible constituents are reached, i.e. until each constituent consists of only a word or a meaningful part of a word.

XLinguae, Volume 13 Issue 1, January 2020, ISSN 1337-8384, eISSN 2453-711X 


\author{
najkrajši zážitok \\ k našim najkrajším zážitkom \\ patrí k našim najkrajšim zážitkom \\ na chalupe patrí $k$ našim najkrajším zážitkom \\ Pobyt na chalupe patrí k našim najkrajším zážitkom.
}

A much more detailed formal description of language means is presented by Zellig $\mathrm{S}$. Harris (1909-1992). Harris followed Bloomfieldian ideas of linguistic description. His Methods in Structural Linguistics (1951) is considered as the definitive formulation of descriptive structural work. Harris's contributions to linguistics include componential analysis of long components in phonology, componential analysis of morphology, discontinuous morphemes, and a substitution-grammar of word- and phrase-expansions that is related to immediate-constituent analysis.

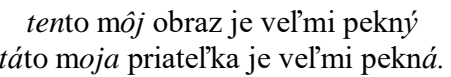

The outlined structure of the Harris's model presents linguistic elements at various places of the utterance (so-called distributionalism). Harrisian distributionalism explicates Bloomfield's affirmation that the form of an utterance and the meaning that it conveys are two aspects of the same thing. Despite the positive contribution of American descriptivism, which favours form over content, this direction in linguistics could not avoid critical acclaim from the oncoming generative and transformational grammar, the theory that focuses on the syntactic structure and semantic component of language. The influence of Bloomfieldian structural linguistics declined in the late $1950 \mathrm{~s}$ and $1960 \mathrm{~s}$ as the theory of generative grammar developed by Noam Chomsky came to predominate. According to Lančarič (2012, pp. 99 - 100), Noam Chomsky's book Syntactic Structures (1928) revolutionised linguistics. Chomsky's nativist (mentalistic) view considers people to be biologically endowed with capability of learning language. That is to say language develops from the so-called universal grammar, which is a set of principles inherited genetically by all people. It enables them to produce and receive unlimited number of utterances. Chomsky is not interested in the speaker's performance (speech), but deals with the speaker's competence, i.e. with the principles that are incorporated in the speaker and help him distinguish well-formed utterances from incorrect ones or decide whether some sequences are possible or not. The only way of getting access to unused, unspoken sentences is through introspection as well as through the use of the speaker's intuitive judgements concerning the acceptability of grammatical structures. Accordingly, Chomsky tries to disclose syntactic principles that are hidden in generative grammar and on the basis of which language generates hypothetical models of all correct sentences. Thus, generative grammar is a set of rules which operate upon a finite vocabulary and generates a set of syntagms.

\title{
The division of applied linguistics
}

The term applied linguistics is very broad and its interpretation varies in contemporary linguistics, e.g. in Russian language - Prikladnaja lingvistika, in English - Applied Linguistics, in German - Angewandte Linguistik. Widdowson (2006) states that despite institutional recognition for the field of applied linguistics, consensus in relation to what the term actually encapsulate remains a long term goal. Generally, Western linguists associate it mainly with language (either native or foreign) teaching and methodology. In Russia, the term applied linguistics occurred in the 1950s in connection with the development of computer technology and the emergence of automated information processing systems. In this sense, the 
synonymous use of computational linguistics, engineering linguistics, machine linguistics is often used, although these synonyms cannot be fully regarded as true synonyms. Each of these disciplines has its own subject-matter and research methods in applied linguistics.

Russian interpretation of the division of applied linguistics focuses on solving practical tasks related to language research and practical use of linguistic theory in other scientific areas. The directions of applied linguistics associated with language research include: lexicography (the theory and practice of compiling, writing and editing dictionaries); linguodidactics (science of language teaching and methodology); terminology science (science of creating and systematizing terms); translation (translation theory). The directions of applied linguistics associated with the application itself include computer linguistics, automatic translation, automatic symbol recognition, automatic speech decoding, automatic word processing - text linguistics, electronic dictionaries, thesauruses, anthologies, corpus linguistics, linguistic expertise, e.g. forensic linguistics, etc. At present, applied linguistics is also understood as a science of practical knowledge of the language use in non-linguistic scientific disciplines and in various fields of practical human activity (Zvegincev, 1968 , p.23).

In western-oriented interpretation of applied linguistics, there is also a controversy surrounding the substance, practice and division of applied linguistics. Al-Khatib (2016, p.446) citing Kramsch (2000, p.317) notes, "the field of applied linguistics speak with multiple voices. It incorporates multi-disciplinary knowledge and is, therefore, of necessity, interdisciplinary." Al-Khatib (20016, p. 447) claims that "contemporary research in applied linguistics expanded to include pedagogical interests, political interests, socio-cultural concerns, socio-cognitive approaches, visual semiotics, in addition to interests and applications that attempt to solve contemporary concerns where language, in all its forms, is the main feature." According to him (ibid, p. 450) "existing sub branches of the field now include: language and education in areas of studies pertaining to first language and additional language; clinical linguistics; neurolinguistics and the study and treatment of speech and communication impairment; psycholinguistics and the study of psychological factors that enable the comprehension and production of language; language assessment and testing; the evaluation of language achievement and proficiency both in first and additional languages; workplace communication and how language contributes to ne nature and power relations in institutional discourse; language planning and decisions about official status of languages and their institutional use; computational linguistics and the use of computers in language analysis and use; forensic linguistics and linguistic evidence in criminal and legal investigation; literary stylistics and the relationship between linguistic choices and literary effects; critical discourse analysis and persuasive uses of language; marketing and politics; translation and interpretation; lexicography and the planning and compiling of bilingual and monolingual dictionaries and thesauri; pragmatics and sociocultural and ethnographic communication.“

In the context of the aforementioned breakthrough in the field of applied linguistics, the question is to what extent it is possible to talk about the application of linguistics in practice and when it is rather a realignment of linguistics with other sciences that help linguistics solve fundamental theoretical and methodological issues of its own research. For instance, UCD School of Languages, Cultures and Linguistics (University College Dublin, Ireland, http://www.ucd.ie/alc/) offers study of fundamental and applied linguistics in its educational programms. The Faculty of Philology of Tver State University, Russia (http://filologia.tversu.ru) offers study of fundamental and applied linguistics. In the curriculum it is declared that the direction

XLinguae, Volume 13 Issue 1, January 2020, ISSN 1337-8384, eISSN 2453-711X 
of fundamental and applied linguistics is the successor of theoretical and applied linguistics that has been there for more than 11 years and their graduates work as translators, managers of departments in the banking sector, business and state companies and tourist offices and also in various analytical centers. Therefore, it follows that applied linguistics has obtained another dimension. It is understood as the application of language in economic sciences. Its aim is the issue of professional economic language (translation of economic lexics from one language to another, language in the banking sphere, language in tourism and hotel industry, language in the commercial sphere, language in advertising, language in human resources and management).

Such breakthrough in the field of applied linguistics can lead to various misconceptions and can bring some chaos regarding the division of applied linguistics into separate scientific sub-disciplines. Moreover, Widdowson (1997) proposes to differentiate between perceptions of linguistics applied and applied linguistics. He explains that applied linguistics can be understood as a kind of linguistics, like historical linguistics or folk linguistics. This presumably allows its practitioners to define an independent perspective on the general phenomenon of language and to establish principles of enquiry without necessary reference to those which inform linguistics. With linguistics applied we do not have this option. Whatever, we do with linguistics; however we apply it, the informing principles which define this area of enquiry, already pre-established, must remain intact. With regard to this, Al-Khatib (2016) claims that linguistics applied is theory-driven application that tests the extent of a specific linguistic feature, while applied linguistics is an autonomous and problem oriented discipline. He (ibid.) adds, while linguistics applied is solely focused on English language teaching (ELT) and its subcategories of English as a second language (ESL), English as a foreign language (EFL) and English as an additional language (EAL), applied linguistics is concerned with all contexts of language use, beyond the classroom.

According to Lyons (1999, p. 35), "theoretical linguistics studies language and languages with a view to constructing a theory of their structures and functions and without regard to any practical applications that the investigation of language and languages might have, whereas applied linguistics has its concerns in the applications of the concepts and findings of linguistics to a variety of practical tasks including (but not solely constrained to) language teaching."

Division of theoretical linguistics is unambiguous. Theoretical Linguistics focuses on the structure of English in all its manifestations, such as phonetics, phonology, morphology, syntax, grammar at large. Further objects of its study are semantics, pragmatics, historical linguistics as well as comparative linguistics. In the system of classification of linguistics as a science it can be considered as the basis of applied linguistics. Within the particular areas of applied linguistics, the narrower and broader meaning of the concept of applied linguistics can be reflected. By the narrower meaning of this term we understand applied linguistics as a linguistic theory applied in linguistic fields, such as translation and interpretation, lexicography, stylistics. By the broader meaning of the term applied linguistics we understand the realignment of linguistics with other scientific disciplines, e.g. psychology, medicine, sociology, mathematics, computer science.

According to Mistrik (1993, p. 263), lexicography is characterized as a branch of linguistics that deals with the theory and practice of compiling dictionaries of different types. In addition to its own linguistic methods of work, it currently utilises mainly the results of modern information and communication technologies (computer processing of lexicographic material, lexical database administration and others). Mistrik (ibid, p. 237) also deals with so called clinical linguistics that can be viewed as the application of linguistic theories, methods and results of descriptive linguistics to the analysis of speech disorders, especially the application of linguistic 
theory to the field of Speech-Language Pathology. Therefore, cooperation of a linguist with a speech pathologist or therapist, with an audiologist, or with another specialists is usually required. Mistrik (ibid, p. 413) views sociolinguistics as a linguistic discipline that has gradually emerged from the sociological research of language. It focuses on the effects of language use within and upon societies and the reciprocal effects of social organization and social contexts on language use. Sociolinguistics overlaps considerably with pragmatics. Ethnolinguistics is characterized as a field of linguistics which studies the relationship between language and culture, and the way different ethnic groups perceive the world. Mistrík (ibid, p. 132) claims that the research of the relationship between language and culture is more likely to be included in sociolinguistics. Altmann (2001, p.1) considers psycholinguistics (or psychology of language) as "the study of the psychological and neurological factors that enable humans to acquire, use, comprehend and produce language." Mistrík (ibid, p. 358) adds that although psychologists had already examined the language and the influence of sociology had also been applied in linguistics, psycholinguistics as a discipline did not become independent until the 20th century. Neurolinguistics can be considered as an interdisciplinary field at the interface of linguistics, psychology and neurology. It draws methods and theories from fields such as neuroscience, linguistics, cognitive science, communication disorders and neuropsychology. It examines the brain mechanisms of speech activity and speech changes in local brain strokes (Mistrik, ibid, p. 296). Computational linguistics is an interdisciplinary field concerned with understanding of written and spoken language from a computational perspective. It is the study of computational approaches to linguistic questions. It examines the possibilities of using electronic and information technologies to describe and process language material (Mistrík, ibid, p. 424).

The position of ELT within the scope of applied linguistics is still open to dispute. On the one hand, Crystal (2001, p. 23) defends the need to associate applied linguistics with English language teaching, "the most well developed branch of applied linguistics is the teaching and learning of foreign languages, and sometimes the term is used as if this were the only field involved." However, Smith (2011) refers to "a current crisis in the relationship between applied linguistics and English language teaching." Smith (ibid.) identifies three substrands of the crisis that underlined the controversy: a crisis of neglect; a crisis of unfulfilled possibilities and a crisis of faith. The crisis of neglect refers to the inadequate treatment of the field of applied linguistics by traditional ELT practitioners. The fossilized views, maintained by academics of the previous decades restricted conceptualizations of the discipline to linguistic driven notions. Thus, applied linguistics, for these academics, remains the application of linguistic theory to practical tasks with the overall aim of improving English language teaching. The crisis of unfulfilled possibilities marked overlooking the interdisciplinarity progression of the principled eclecticism that applied linguistics offered. Proponents of disciplinarity defended discipline orthodoxy within area studies. However, contemporary scholars argue that disciplinarity, or the belief that academic work should suffice itself by its internal standards, can no longer be valid in the twenty-first century. Frodeman (2013) contends that living in an age where academic autonomy is increasingly monitored by greater demands for accountability to society would require academics to recognize interdisciplinary trends and work with them, rather than mindlessly dismiss them. According to Grabe (2010), orthodox views on pure disciplines were no longer sufficient for the state of knowledge required in the twenty-first century. The crisis of faith identifies doubts in the minds of conformist ELT proponents and disbelief in the ability of applied linguistics to embrace vast applications of language, above the clause level, that can inform long established theories.

XLinguae, Volume 13 Issue 1, January 2020, ISSN 1337-8384, eISSN 2453-711X 
It is inevitable to emphasize that the position of linguodidactics (theory of foreign language teaching - mainly Russian interpretation) in the system of applied linguistics in relation to western oriented applied linguistics and its sub-discipline ELT is even more indefinite and open to dispute. It has already been mentioned that Western linguistic schools, in particular, associate applied linguistics with foreign language teaching, including the methodology of teaching the language as native and foreign. In Europe, didactics (from Ancient Greek "didáskō" = I teach, educate) is the art, or science of teaching. According to Zierer - Seel (2012), this term is stemming from the German tradition of theorizing classroom learning and teaching. Didactics serves as a major theory in teacher education and curriculum development, especially in German-speaking and Scandinavian countries, as well as in the Russian Federation. Didactics is an independent and legitimate science, it has its subject and research methods. It is mainly related to a specific subject of education, focusing on the selection of educational objectives, formulation of educational objectives, formulation of teaching and learning objectives, innovation of didactic principles, elimination of transmissive (lecure) teaching methods, enhancing activating teaching methods and overall personality development. Generally, didactics deals with the content of education, methods, principles and forms of teaching, and the interaction between a teacher and a student. According to Doulik et al. (2015), within the context of science, the didactics (general didactics) is a traditional part of general pedagogy, from which the field didactics were step by step singled out. Doulik et al. (ibid.) maintain that field didactics are often understood as methodologies dealing with methods and forms of instruction of a given subject rather than dealing with learning content and its didactic transformation. They emphasize the fact that common features of field didactics (including foreign language didactics) can be summarized as follows: their overlapping character is increasing, but step by step they become self-reliant independent disciplines, not been an 'appendix' of the field; they have a weaker relation to the field, pedagogy and psychology, but they support psychodidactics, neurosciences, pedagogical psychology, cultural anthropology, sociolinguistics etc., and general didactics; they define own theoretical paradigms, research topics and methodology; they form own scientific schools - new doctoral study programmes are accredited in field didactics (including foreign language didactics), as well as new possibilities of habilitation and inauguration procedures appeared. Doulík et al. (2015) citing Píšová assert the relation linguistics versus foreign language didactics is significantly asymmetric. The impact of linguistics on the reflection of processes in the foreign language instruction started with linguistic structuralism and has been running up to now within the concept of foreign language didactics as applied linguistics. This approach is an anachronic misconcept significantly disturbing the process of foreign language didactics emancipation. It also shows how important the didacticians for the foreign language didactics and other field/subject didactics are. And, there is a disproportion in the concept of education - the subject teacher should be equipped with other competences than the field/subject didactician. The term linguodidactics (a general theory of foreign language teaching) was introduced in 1985 by N. M Shanskiy (Russian linguist and linguodidactician). It was acknowledged as an international term at the International Association of Russian Language Teachers in 1975. Some encyclopedias (e.g. Encyklopedičeskij slovar russkogo jazyka) further characterize linguodidactics as a science examining general principles of learning a foreign language, the specifics of the content, methods and tools for teaching a foreign language, depending on didactic goals, tasks and the nature of study material, monolingualism or bilingualism, regarding the stages of learning, and the intellectual and language level of learners. The question is, does it reflect so called subject/field didactics (or subject-matter teaching and learning), in particular, foreign language didactics, or mother tongue teaching, in which the 
processing of linguistic material is conducted, or does it deal with the results of linguistics that are applied to the didactics? Do we consider realignment of the two individual disciplines (linguistics and didactics), or are the two disciplines hierarchically related to each other as the main and auxiliary discipline? Can we consider linguodidactics as applied linguistics? Which linguistic results are applied in practice within the framework of linguodidactics? Obviously, the process of foreign language learning and acquisition does not concern merely linguistics. It is a complex process that relates to psychology, pedagogy as well as sociology. From this perspective as well as from the perspective of the language learning and acquisition processes, it can be assumed that the results of psycholinguistic theory and sociology help to clarify the complexity of processes that take place in the process of learning and acquisition of a native, or a foreign language. According to Rizeková (2013, p. 150), linguodidactics is an interdisciplinary field of science in which language knowledge is combined with didactics. The subject-matter of linguodidactics is to examine the educational aspect of the educational process, its content, methods and ways of applying scientific knowledge of linguistics in language teaching. Rizeková (ibid.) claims that in the 1980s, the interest of linguists began to shift from system linguistics towards the pragmatics of communication. She also emphasizes the fact that the focus of linguistics research, which was aimed at the real language user and his/her communication skills, also brought about significant changes in foreign language didactics. Dulebová (2012, p. 67) even considers realignment of linguistics with area studies, defining it as the so-called „lingvoreálie“ (Slovak term). Dulebová (ibid.) sees linguistics as a leading discipline that is formed in the context of a" communication-pragmatic turnover in linguistics". According to her, it is is currently in the stage of formulating its bases and methodological procedures in order to examine the linguistic aspects of the landscape of the country, i. e. language units referring to the specifics of a given culture. From the point of view of the current culturological approach to foreign language linguodidactics, foreign language didactics can be considered as an applied discipline. It is based on its own methodology utilising the results of theoretical linguistics. Kostrub et al. (2017, p. 30) distinguish between general didactics and specialised didactics. Kostrub et al. (ibid.) consider linguodidactis as a field didactics that uses the results of theoretical linguistics, psycholinguistics, sociology and computational linguistics, thanks to which it can didactically organize the curriculum, design its elements as well as particular lessons.

\section{Perspectives of contemporary applied linguistics}

At present we usually use the term applied linguistics without specifying its relation to linguistics. If we consider linguistics as a science with a very broad field of study dealing with language learning in general, then applied linguistics should be considered as one area of linguistics (see Figure 1). 


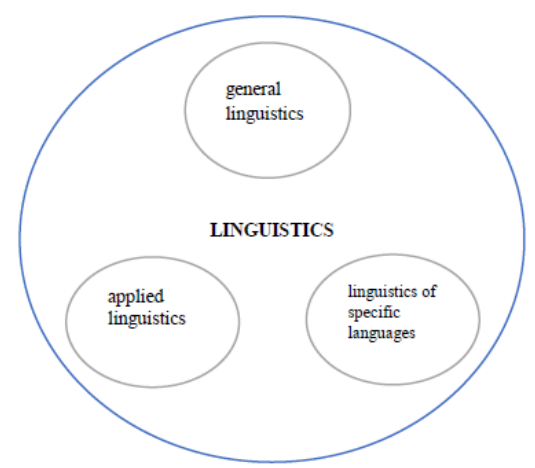

Fig. 1 Relationship between linguistics and applied linguistics

Therefore, if we distinguish applied linguistics as a special area of linguistic science, the question is: what is the ratio of theoretical and applied aspects, what are the characteristics of other linguistic fields and what is the characteristic feature of applied linguistics? Are there purely theoretical and truly applied areas? According to Merriam-Webster Dictionary (https://www.merriamwebster.com/dictionary/application), the term application is an act of putting something to use (e.g. application of new techniques). Obviously, application is supposed to lead to something practical that serves the use and helps humankind. Scientific disciplines are primarily applied, as the theoretical results of scientific disciplines (e.g., physics, chemistry, mathematics) can serve to create something that will help everyone in practice. Regarding the term application within humanities can lead to miscellaneous interpretations. Then, applied linguistics has to be viewed as comprising both theoretical and applied aspects. If we try to name the components of a linguistic field, then its various disciplines (in the narrower sense), e.g. studying grammar, vocabulary, stylistics, etc. cannot be considered in isolation from the socalled linguistic field. On the one hand, learning vocabulary involves systematization leading to the identification of general principles and the building of theories about the structure of words in language, as well as comparative studies, or even typological statements concerning some universals of human language. On the other hand, lexical research can also be aimed at compiling dictionaries, thereby achieving some of the applied goals (setting etymology values, formal word variations, etc.) to satisfy the practical interests of readers of different categories, from schoolchildren to adults, from general readers to experts - linguists). Thus, the applied problems cannot be solved without preliminary theoretical studies leading to the formulation of general principles, and the results obtained can therefore be used as the basis of theoretical constructions. A similar situation occurs when compiling language grammar: we can attribute it to either Applied Linguistics (if we mean a grammar book that will be used to teach a native or a foreign language at school) or to the field of basic linguistics research; in both cases, both aspects of language learning are closely interrelated and are separated only by the ultimate goal.

It follows from the aforementioned that within linguistics there are immediate application areas, which in turn have certain theoretical foundations and areas which are predominantly of a theoretical or fundamental nature. It is difficult to find a suitable name for an area that has purely fundamental nature, especially when we talk about its essence with regard to the so-called non-application tasks that can be solved. Perhaps, it would be appropriate to call it "basic language research" (see Figure 2). 




Fig. 2 Relationship between linguistics and basic language research

There are two fundamental directions in modern science: on the one hand, profound specialization in individual sectors (as a result of discovery, new aspects that require deeper knowledge of appropriate means), and on the other hand, the pursuit of an interdisciplinary or multidisciplinary approach (as a result study of phenomena whose universality has been revealed in the process of evolution of science, and as an effort to achieve unity in plurality). In essence, it is the contradiction between the individual and the general, which are also in dialectical unity.

The status of applied linguistics in network of sciences is characterized by the fact that applied linguistics must be an area that uses linguistic data itself, drawing on data from other disciplines, using interdisciplinary methods and tools to be useful to other disciplines on its own. For instance, when elaborating a foreign language textbook for children speaking foreign languages, it is necessary to take into account psycholinguistic aspects (the influence of the child's mother tongue, etc.), psychological aspects (arrangement of material according to human memory abilities, age characteristics, etc.), pedagogical and didactic aspects (cross-curriculum integration, connection with subjects already completed or concurrently studied), methodology (selection of teaching methods focused on the content of each), sociocultural and sociolinguistic aspects, etc. When dealing with the issues of automatic translation, applied linguistics cannot ignore cybernetics, mathematics, computer engineering, programming, etc. (see Fig. 3) 


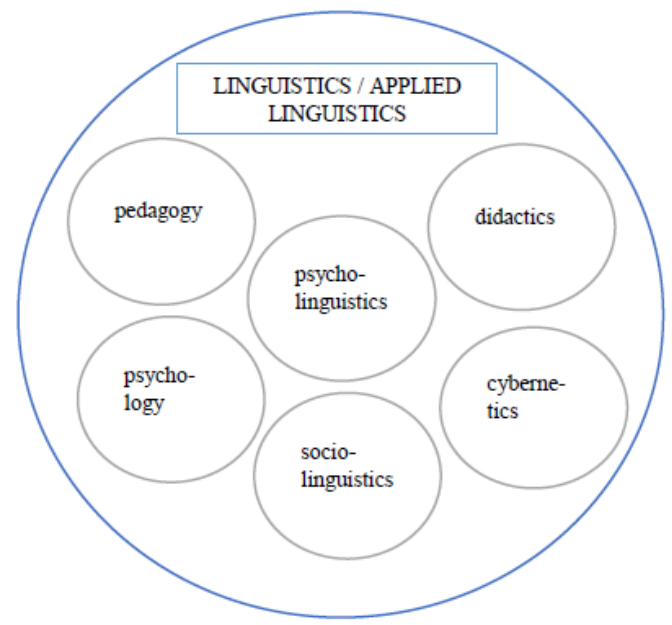

Fig. 3 Relationship between linguistics, applied linguistics and other scientific fields

The diversity of contemporary applied linguistics is primarily related to the practical activities of humankind. The most promising application areas are hypertext technologies, which are directly connected with the development of the global Internet network. The level of hypertext acquisition by linguists is currently not at a satisfactory level since hypertext research is not always seen as a natural continuation of linguistic activity in studying and researching the principles of text organization and understanding. The design and purposeful development of hypertext-oriented software applications are practically impossible without utilising the basic knowledge of the language system. Computer technology is also related to rapidly developing issues of computer text design, which also has same linguistic potential. With the help of software it is possible to work with the printed text of a book, magazine, newspaper and thus compose the text with display elements into a single compact whole. Here, the text acts as a display element and the display as part of the text.

The current trends in applied linguistics include its application to a particular social, technical, economic or political field. Special attention has recently been paid to political linguistics. However, the definition of this interdisciplinary discipline is still disputable. The term itself, as stated by Macho (2012, p.18), is mainly known in the German literature, which is considered to be a redefined term in the field of language and political communication. The term politolinguistics has not been more precisely determined yet. Macho (ibid.) mentions a number of authors dealing with the terminological definition of the term, for instance, Burkhardt (1996), who understands it very generally a linguistic discipline dealing with the research of political language, political language of the media, as well as the language of politics and the language of politicians. In German literature, the terms "Politiksprache" and "Politikersprache" have been used. Politolinguistics can be characterized as a boundary discipline combining linguistics and political science and can be considered part of applied linguistics. According to Burkhardt (1996, p. 75), the role of political linguistics is the historiography of the political language in describing the historical evolution of the language and the critical way of coping with political communication. Analysis and criticism of the political language represents an important social and political role of linguistics that interferes with practices of humankind. He (ibid.) distinguishes and divides analytical methods of political linguistics into lexical-semantic and pragmatic levels. As the above-mentioned, the 
exact definition of the term political linguistics or the language of politics is currently not clear-cut from the linguistic point of view. Obviously, it is not purely a linguistic phenomenon and it would be to interpret the relationship between linguistics and political communication unilaterally. Seresova (2017, p.17) claims that political language can be understood as a separate act of speaking which involves a particular activity concurrently. She (ibid., p. 18) deals with the functions of the language of politics, the influence of the speaker on the recipient, and, in general, she looks at linguistic acts by which, in written or oral form, the speaker attempts to influence the political will of the state in public or within a public institution. Dulebova $(2011, \mathrm{p} .3)$ describes political linguistics as interdisciplinary science emerging at the interface of humanities and social sciences. She (ibid.) asserts that it is realized as interdisciplinary research at the interface of linguistic fields, media studies and media communication, sociology, politology, psychology and other humanities and social sciences, whereas the term political linguistics is often not even explicitly used. Contrary, Petrenko - Potapova $(2014$, p. 482$)$ state that political linguistics can be considered as the part of modern politics. They emphasize the fact that the main principles of methodology in this research are connected with the key ideas of structuralism and poststructuralism in the sphere of language. The interest in political linguistics opens the field of political communication for contemporary investigations. Stradiotová (2017, p. 137) views the relationship between linguistics and political science through the language of a political blog. She (ibid.) claims although the use of the internet in Slovakia did not boom until the late 1990s, the first blogs had begun to emerge a few years earlier. Initially they had the form of reports that were chronologically arranged. The effect of the blog was also quickly perceived and understood by the election campaign agencies and marketing agencies whose experts began to use it as an important means of communication between the politician and the citizen, respectively the voter. In 2004, they used the blog in the US presidential election campaign as well as in Germany. The nature of blogging is different. If we look at the most popular portals that provide bloggers with space for publishing their texts (in this case, the SME daily blog, www.sme.sk), we can see a really wide range of text genres ranging from standard readers' comments on political events, travelogues, as well as personal expression of emotional experiences expressed in poetry. Based on the analysis of selected political texts through blogs there can be various language functions identified, such as persuading, hypothesizing, making claims, making predictions, etc. Stefancik - Dulebova $(2017$, p. 7) consider the relationship between politics and linguistics as a turnaround as they emphasize that almost half a century ago, the communication-pragmatic turn in linguistics made it possible to expand and deepen the research into the analysis of language and politics interaction. Linguists have been interested in the language of totalitarian regimes, both clerical fascism and communist, spoken and written language of verbal interaction in parliament, including speeches and reactions to speeches (factual remarks), legislative process texts, vocabulary of political institutions or the language used by ministers within internal communication. Linguists have also been keen on the lexical peculiarities of the language of ideology, political party programs, typical pre-election slogans, speeches, or New Year's speeches of world leaders. Zeman (2008, p.253) regards language as an effective weapon. He (ibid.) analyzes the relationship between language and thought, taking into account the power of language, symbols, metaphors, pejorative meanings and non-verbal means of communication. The semantics, ways of communication, understanding and the ability of each language to take the form that its users need in order to achieve their goals (often political ones) are at the heart of the cultural continuity of modern times in terms of communication. Similarly, Liskova (2017, p. 141) emphasizes that many wars ended in victory or loss just due to the choice of language means. She (ibid.) states that verbal expressions in

XLinguae, Volume 13 Issue 1, January 2020, ISSN 1337-8384, eISSN 2453-711X 
the media have deluged the public, and the language serves not only as a means of information, but also a tool influencing our opinions and attitudes.

\section{Conclusion}

The position of applied linguistics in contemporary linguistic sciences is undeniable and legitimate. There is no doubt that much research has been done in this area, starting with the American structuralism and subsequent generative grammar. Its structure and division has been reappraised for many years due to its interdisciplinary character, and we convinced that the classification of applied linguistics itself, given the current state of rapid development of sciences requiring linguistic assistance, is complex and would require more scientific research. Therefore, it would be appropriate to deal with it from a broader and narrower meaning of the basic term "application". Special attention should be paid to those fields which help linguistics to clarify linguistic issues themselves, such as psycholinguistics, neurolinguistics, sociolinguistics. We see these disciplines as a realignment of linguistics with other self-existing sciences, such as linguistics and sociology, linguistics and mathematics, linguistics and information technology, linguistics and didactics. This is a broader meaning of the term, when the sciences themselves help to clarify some of the linguistic issues, but they are not purely linguistic sciences. In our opinion, the term "linguodidactics" should be viewed more cautiously with regard to its integration into applied linguistics since it is a field of pedagogy and thus it cannot be unequivocally characterized as a purely linguistic one. Linguodidactics can be considered as the use of particular linguistic theories applied withing the didactic transformation of the linguistic material, or as the arrangement of the components of the (native, second, or foreign) language teaching process. Thus, a linguodidactician can choose whether $\mathrm{s}$ /he would design grammatical and lexical curriculum following the results of American structuralism or Chomsky's generative grammar. To sum up, no field of scientific endeavour is immune to criticism and thus the reappraisal of scientific research results and subsequent statements is natural.

\section{Bibliographic references}

AL-KHATIB, H. 2016. Issue of Identity and Boundary between Applied Linguistics and English Language Teaching. In: Arab World English Journal (AWEJ), vol. 7, n.3. pp. $445-462$. SCOPUS

ALTMANN, T. M. 2001. Psycholinguistics. In: Review British Journal of Psychology, Britain: Great Britain the British Psychological Society, pp. 129-170.

APRESYAN, Y, D. 1967. Ideyi i metody sovremennoy strukturnoy lingvistiky. Moskva: Nauka.

BAAL. 1994. Recommendations on Good Practice in Applied Linguistics. British Association for Applied Linguistics.

BERNS, M. 2010. Concise Encyclopedia of Applied Linguistics. Amsterdam: Elsevier.

BURKHARDT, A. 1996. Politolinguistik. Versuch einer Ortsbestimmung. In: KLEIN, J., DIEKMANNSHENKE, H. J. (Hrsg.): Sprachstrategien und Dialogblockaden. Linguistische und politikwissenschaftliche Studien zur politischen Kommunikation. Berlin - New York, pp. 75 - 100.

CERNY, J. 1996. Dejiny lingvistiky. Olomouc: Votobia.

CHARLES, C. F. 1952. The structure of English, an introduction to the contractionnof English sentences. In: CERNY, J. 1996. Dejiny lingvistiky. Olomouc: Votobia, 207 p. COOK, G. 2010. Applied Linguistics. Oxford: University Press.

CORDER, S. P. 1974. Error Analysis. In: ALLEN, J. P. B., CORDER, P. 1974. (Eds). Techniques in Applied Linguistics (The Edinburgh Course in Applied Linguistics). London: Oxford University Press. 
CRYSTAL, D. 2001. A Dictionary of Linguistics and Phonetics. New York: Blackwell publishers.

DAVIS, A. 2004. The Handbook of Applied Linguistics. Hong Kong: Blackwell Publishing Ltd.

DOULIK, P. - SKODA, J. - SIMONOVA, I. 2015. Foreign Language Didactics in Context of the Field: Case Study of the Czech Republic. In: Advance Science Letters. USA: American Scientific Publishers.

DULEBOVA, I. 2011. Podoby sucasnej ceskej a slovenskej politickej lingvistiky. In: Jazyk a kultura vol. 2, n. 8. Available online: http://www.ff.unipo.sk/jak/8_2011/dulebova.pdf

DULEBOVA, I. 2012. Realie a lingvorealie alebo o otazke kulturologickeho smerovania. In: Vyucovanie rustiny ako cudzieho jazyka vo viackulturnom priestore. Presov: Presovska univerzita, $67 \mathrm{p}$.

FRODEMAN, R. 2013. Sustainable Knowledge: a Theory of Interdisciplinarity. USA: Palgrave Macmillan.

GORODETSKIY, B. 1983. Novoye v zarubezhnoy lingvistike. Prikladnaya lingvistika. Moskva: Raduga.

GRABE, W. 2002. Applied linguistics: an emerging discipline for the twentieth century. In: KAPLAN, B. R. (Eds.) Oxford handbook of Applied Linguistics, New York: Oxford University Press. pp. $3-12$.

GRABE, W. 2010. 'Applied Linguistics: a twenty first century discipline'. In:

KAPLAN, R. (Eds) The Oxford Handbook of Applied Linguistics. Oxford: Oxford University Press.

JAKOBSON, R. 2013. Linguistics in its relation to other sciences. In: KIEFER, F., STERKENBURG, P. van. (Eds) 2013. Eight Decades of General Linguistics. The History of CIPL and Its Role in the History of Linguistics, vol. 1,

JOHNSON, K. - JOHNSON, H. 1998. Encyclopedia Dictionary of Applied Linguistics. New York: Springer.

KOSIKOVA, K. et al. 2002. Vseobecny encyklopedicky slovnik. Praha: Ottovo nakladatelstvi.

KOSTRUB, D. - TOTHOVA, R. - FERKOVA, St. 2017. Ziak, ucitel a vyucba. Presov: Rokus.

KRAMSCH, C. 2000. Language and Culture. Shanghai: Shanghai Foreign Edcuation Press.

KUBRIK, A. E. 2019. Vvedeniye v nauku o yazyke. Moskva: Buki Vedi.

LANCARIC, D. 2012. Essentials of Linguisitcs. Bratislava: Z-F LINGUA.

LEITNER, G. 1991. English Traditional Grammars: an international perspective. Amsterdam/Philadelphia: Library of Congress.

LYONS, J. 1999. Language and Linguistics. Cambridge: Cambridge University Press. MACHO, M. 2002. Terminologicke a metodologicke vychodiska skumania jazyka politickeho diskurzu. In: XLinguae, vol. 1, Nitra: SVO, s. r. o.

McCARTHY, M. 1998. Spoken Language and applied linguistics. Cambridge: University press.

MISTRIK, J. et al. 1993. Encyklopedia jazykovedy. Bratislava: Obzor.

PETRENKO, V. V. - POTAPOVA, A. S. 2014. Political Linguistics as a Constituent Part of Modern Political Theory. In: Procedia - Social and Behavioral Sciences, vol.154, pp. $482-485$.

RIZEKOVA, I. 2014. Vyskum v lingvodidaktickych disciplinach a pedagogicky proces. In: Cudzie jazyky v premenach casu, 4, Bratislava: Vydavatelstvo EKONOM.

SABOL, J. - ONDRUS, S. 1987. Uvod do studia jazykov. Bratislava: SPN.

SAUSSURE, F. de. 1986. Course in general linguistics (3rd ed.). Chicago: Open Court Publishing Company, pp. $9-10,15$.

XLinguae, Volume 13 Issue 1, January 2020, ISSN 1337-8384, eISSN 2453-711X 
SERESOVA, K. 2017. Jazyk politiky a jeho funkcie. In: STEFANCIK, R. (ed.) 2017. Jazyk a politika. Na pomedzi lingvistiky a politologie II. Bratislava: Vydavatelstvo EKONOM, pp. 17-18.

SHANSKIY, N. M. 1985. Russian linguistics and linguodidactics. Moskva: Russkiy yazyk.

SCHMITT, N. 2010. Introduction to Applied Linguistics. London: Hodder Education.

SMITH, R. 2011. Plenary address. Crisis between Applied Linguistics and English Language Teaching. International Conference on Multiple Perceptual Frames on English Language Teaching and Research. Centre of Applied Linguistic Research (CALR). Arab Open University in Lebanon. Beirut, March 22.

STEFANCIK, R. - DULEBOVA, I. 2017. Jazyk a politika. Bratislava: Vydavatelstvo EKONOM.

STRADIOTOVA, E. 2017. Jazyk politického blogu. In: STEFANCIK, R. (ed.) Jazyk a politika. $\mathrm{Na}$ pomedzi lingvistiky a politologie II. Bratislava: Vydavatelstvo EKONOM, $137 \mathrm{p}$.

WIDDOWSON, H. G. 1984. Models and fictions. In: WIDDOWSON, H. (Eds.) Explorations in Applied Linguistics 2. Oxford: Oxford University Press, pp. $21-27$.

WIDDOWSON, H. G. 2000. On the limitations of linguistics applied. Applied linguistics, 21(1), pp. $3-25$.

WIDDOWSON, H. G. 2006. Applied linguistics and interdisciplinarity. International Journal of Applied Linguistics, vol. 16, n. 1. Blackwell Publishing Ltd.

ZIERER, K. - SEEL, N. M. 2012. General Didactics and Instructional Design: eyeslike twins A transatlantic dialogue about similarities and differences, about the past andthe future of two sciences of learning and teaching. In: Springer Plus. A Springer Open Journal. London.

ZVEGINCEV, V. A. 1968. Teoreticeckaya i prikladnaya lingvistika. Moskva:

Prosveshtcheniye.

Words: 9245

Characters: 65487 (36,38 standard pages)

PhDr. Roman Kvapil, PhD.

Department of Romance and Slavic languages

Faculty of Applied Languages

University of Economics in Bratislava

Dolnozemská cesta 1

85232 Bratislava

Slovakia

PaedDr. Martina Šipošová, PhD.

Department of English Language and Literature

Faculty of Education

Comenius University in Bratislava

Račianska 59

81334 Bratislava

Slovakia 